\title{
A scanning electron microscopic evaluation of different root canal irrigation regimens
}

\section{Avaliação por microscopia eletrônica de varredura de diferentes regimes irrigantes no canal radicular}

\author{
Mônika Chaves Medici* \\ Izabel Cristina Fröner**
}

\begin{abstract}
The purpose of this study was to assess the effectiveness of endodontic irrigants in removing the smear layer from instrumented root canal walls using Scanning Electron Microscopy (SEM). The endodontic irrigants used were: $1 \%$ sodium hypochlorite $(\mathrm{NaOCl}) ; 1 \% \mathrm{NaOCl}$ mixed to $17 \%$ EDTAC; $2 \%$ chlorhexidine gel; and Ricinus communis gel. Photomicrographs of the middle and apical thirds were evaluated with the aid of the Fotoscore v. 2.0 software. The results indicated that the mixture of sodium hypochlorite and EDTAC completely removed the smear layer from dentinal walls. The other endodontic irrigants were not as efficient in cleansing the root canals. DESCRIPTORS: Smear layer; Root canal irrigants; Chlorhexidine; Ricinus communis.
\end{abstract}

\begin{abstract}
RESUMO: A proposta deste estudo foi avaliar, por meio de microscopia eletrônica de varredura (MEV), a efetividade dos irrigantes endodônticos na remoção da "smear layer" das paredes dos canais radiculares instrumentados. Os irrigantes endodônticos utilizados foram: solução de hipoclorito de sódio a 1\%; solução de hipoclorito de sódio a $1 \%$ misturado ao EDTAC a 17\%, gel de clorexidina a 2\% e gel de Ricinus communis. Fotomicrografias dos terços médio e apical foram avaliadas com o auxílio do software Fotoscore - versão 2.0. Os resultados indicaram que a mistura da solução de hipoclorito de sódio e EDTAC removeu eficientemente a "smear layer" das paredes dentinárias. Os demais irrigantes endodônticos não foram tão eficientes na limpeza dos canais.
\end{abstract}

DESCRITORES: Camada de esfregaço; Irrigantes do canal radicular; Clorexidina; Ricinus communis.

\section{INTRODUCTION}

Despite the outstanding advance reached in all fields of dental research, mainly in the last two decades, search for the ideal irrigant solution still challenges Endodontics and therefore great effort has been focused on assessing the potential of different substances for root canal irrigation.

A major goal of endodontic therapy is to provide the complete decontamination of the root canal system. Root canal asepsis is attempted by means of a series of sequential steps of paramount importance, among which mechanical instrumentation and chemical irrigation during the cleansing process are considered the most remarkable.

Solution of sodium hypochlorite $(\mathrm{NaOCl})$ has been shown to be a solution with low toxicity and with the ability to dissolve organic material, hence exhibiting great potential to remove the debris produced during chemomechanical root canal preparation $^{9}$. Since then, sodium hypochlorite solution has been the most widely used endodontic irrigant and is currently available in different concentra- tions, associated or not to other substances or creams.

Ethylenediaminetetracetic (EDTA) has been used as an irrigant solution aiding the removal of inorganic components of the smear layer ${ }^{21,25}$. When it is associated with Cetavlon (EDTAC), it exhibits lower surface tension, better efficiency and quicker action in root canal therapy than the original formulation ${ }^{11}$.

Several researchers have pointed out the potential of chlorhexidine gluconate as a safe and effective antibacterial medicament for use in endodontic therapy ${ }^{1,17}$. Chlorhexidine gluconate, a broad-spectrum antimicrobial agent that can be successfully used either as an irrigant or an intracanal medicament ${ }^{15}$, disinfects the dentinal tubules and adsorbs onto the root canal dentin walls. Studies have disclosed that, as result of such property, root dentin treated with chlorhexidine seems to acquire antimicrobial substantivity ${ }^{17,24}$. Moreover, chlorhexidine is reported to be relatively

\footnotetext{
* MSc; **Associate Professor - Department of Restorative Dentistry, School of Dentistry of Ribeirão Preto, University of São Paulo.
} 
Medici MC, Fröner IC. A scanning electron microscopic evaluation of different root canal irrigation regimens. Braz Oral Res 2006;20(3):235-40.

nontoxic to periapical tissues ${ }^{16}$ and therefore may be well indicated as a reliable option for patients allergic to sodium hypochlorite ${ }^{13}$.

ENDOQUIL $^{\mathrm{TM}}$, a 3.3\% Ricinus communis detergent (Poliquil, Polímeros Químicos LTDA., Araraquara, São Paulo, Brazil) has produced good results as an endodontic irrigant, and has shown antimicrobial activity similar to that of a $0.5 \%$ solution of sodium hypochlorite when used in the treatment of root canals with pulpal necrosis ${ }^{6}$. Endoquil was effective against Gram-positive microorganisms and a $0.5 \%$ solution of $\mathrm{NaOCl}$ was effective only against $S$. aureus ${ }^{18}$. This substance was also reported to increase root dentin permeability similarly to a $0.5 \%$ solution of $\mathrm{NaOCl}$ and a $0.4 \%$ papaine gel ${ }^{22}$.

Review of the literature shows that there is lack of reported researches evaluating the use of both $2 \%$ chlorhexidine gluconate gel and Ricinus communis gel as endodontic chemical agents and their effectiveness to remove the smear layer during root canal instrumentation. Therefore, the goal of this study was to assess, by means of scanning electron microscopy, the debridement ability of $2 \%$ chlorhexidine and Ricinus communis gels, used as irrigants, on the middle and apical thirds of root canals during endodontic chemomechanical preparation, and to compare the results to those obtained with a $1 \%$ solution of $\mathrm{NaOCl}$ and with a $1 \%$ solution of $\mathrm{NaOCl}$ mixed to $17 \%$ EDTAC.

\section{MATERIAL AND METHOD}

Twenty-four sound mandibular single-rooted human premolars with completely formed apexes were used in this study. The teeth had been extracted for orthodontic purposes within a sixmonth period.

Teeth were randomly assigned to four groups of equal size $(n=6)$, according to the irrigation regimen adopted: Group I - a 1\% $\mathrm{NaOCl}$ solution (Faculdade de Odontologia de Ribeirão Preto-USP; Ribeirão Preto, São Paulo, Brazil); Group II - a mixture, at a $1: 1$ ratio, of a $17 \%$ disodium EDTAC solution and a $1 \% \mathrm{NaOCl}$ solution (Faculdade de Odontologia de Ribeirão Preto-USP; Ribeirão Preto, São Paulo, Brazil); Group III - a 2\% chlorhexidine gluconate gel (Faculdade de Ciências Farmacêuticas de Ribeirão Preto-USP; Ribeirão Preto, Brazil); Group IV - a Ricinus communis gel (Instituto de Química de São Carlos-USP, São Carlos, São Paulo, Brazil).

Conventional access was made through the crowns and the working length was determined
$1 \mathrm{~mm}$ short of the apex with a \#10 file. Root canals were manually instrumented according to a step-back type of instrumentation using sequential Dyna-flex K-type files (DYNA ${ }^{\mathrm{TM}}$-FFDM endodontic instruments, Bourges, France) up to size \#35. For each experimental group, a new ensemble of files was used.

First, the root canals were irrigated with distilled and deionized water, aspirated and then filled with the tested endodontic irrigants through the pulp chamber using $3 \mathrm{ml}$ disposable syringes with non-beveled 40-6 hypodermic needles. The root canals were tapered in such a way that each endodontic file was used for no longer than 1 minute and 30 seconds. Each time the files were substituted, the canals were thoroughly rinsed with distilled water, aspirated and refilled with a new quantity of the chemical agents. After final irrigation with $1.0 \mathrm{ml}$ of distilled and deionized water, the root canals were carefully dried with paper points. Then, using a diamond disk mounted on a low-speed handpiece, longitudinal and transversal grooves, which did not penetrate into the canal, were prepared along the buccal and lingual surfaces of each root. Afterwards, the roots were carefully fractured with the aid of a chisel and a surgical mallet. The crowns and cervical thirds of the roots were discarded. The middle and apical thirds were divided, thereby providing two sections from each portion.

The roots were mounted on stubs, put in a vacuum chamber, sputter coated with gold-palladium $\sim 35 \mathrm{~nm}$ thick with a sputter coater for SEM evaluation (JEOL-890, JSM 5410, JEOL Technics Co.; Tokyo, Japan).

A standardized series of photomicrographs at a $350 \mathrm{X}$ magnification was obtained of the middle and apical thirds for comparative purposes. The images were digitized and transmitted to a personal computer to be analyzed using Fotoscore - v 2.0 software (developed by Guerisoli $\left.{ }^{10}, 2002\right)$, developed for Windows, and entered to an Access database modified by a VBA code ${ }^{10}$. This software allows that the photomicrographs of the sections be compared to a set of three standardized "map photomicrographs" of dentin surface. Three independent examiners, which knew the program, analyzed the photomicrographs and attributed scores to them, by comparing their appearance to those of the proposed "map photos". The scores ranged from 1 (absence of smear layer with the orifices of dentinal tubules opened) to 4 (orifices of dentinal tubules completely obliterated by smear layer) and indicated the debridement ability of the 
Medici MC, Fröner IC. A scanning electron microscopic evaluation of different root canal irrigation regimens. Braz Oral Res 2006;20(3):235-40.

tested chemical agents. Data were submitted to non-parametrical statistical analysis using the Kruskal-Wallis, Dunn and Wilcoxon tests (GMC program, Faculdade de Odontologia de Ribeirão Preto-USP, Ribeirão Preto, São Paulo, Brazil).

\section{RESULTS}

Statistical analysis of the data using the Kruskal-Wallis test showed differences at the 0.01 significance level among the irrigants used for root canal chemomechanical instrumentation.

Complementing the analysis, the Dunn test disclosed that the mixture of a $17 \%$ solution of disodium EDTAC and a $1 \%$ solution of sodium hypochlorite yielded the best results in cleansing the root canal walls, which were statistically different from those of the other irrigants $(p<0.01)$.
The $17 \%$ solution of EDTAC $+1 \%$ solution of sodium hypochlorite (Figures 1 and 2) completely removed the smear layer from the instrumented root dentin, leaving the dentinal tubule openings exposed. On the other hand, the $1 \%$ solution of sodium hypochlorite (Figures 3 and 4), the $2 \%$ chlorhexidine gel (Figures 5 and 6) and the Ricinus communis gel (Figures 7 and 8) showed statistically similar results, but none of these agents was able to cleanse the root canals surface as effectively as the mixture $17 \%$ EDTAC $+1 \%$ sodium hypochlorite.

The Wilcoxon test showed that, regardless of the irrigant used for root canal preparation, no statistically significant difference could be found between the middle and apical thirds of the roots, as regards the amount of smear layer that remained covering the dentin surface.
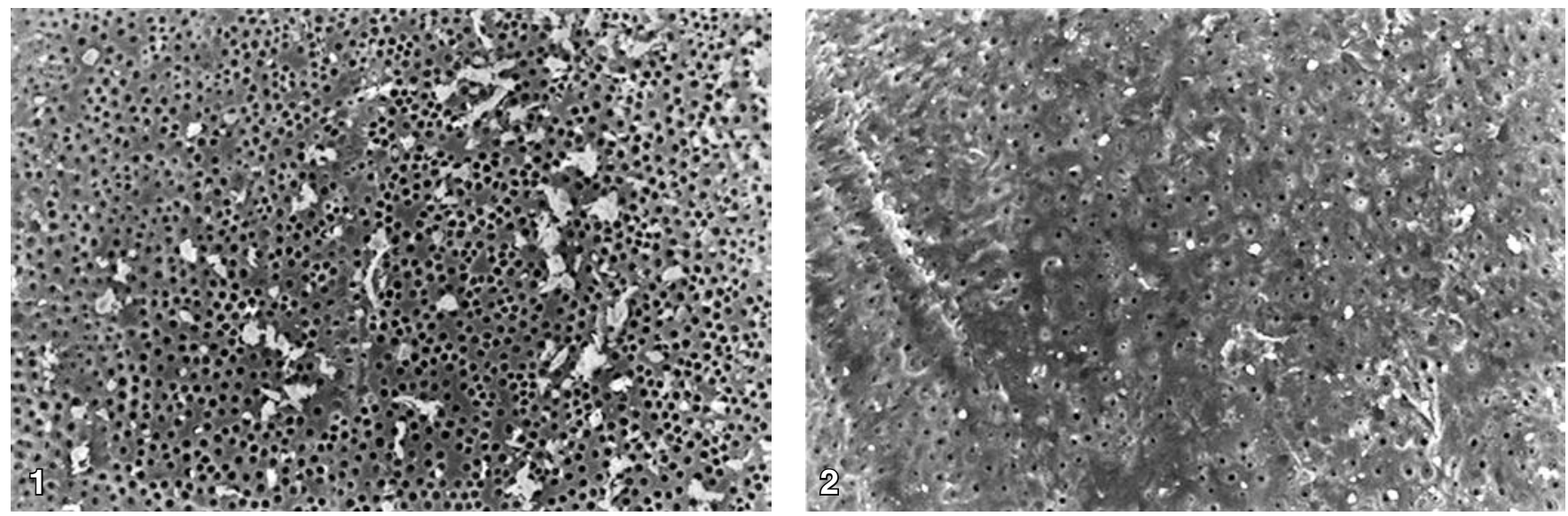

FIGURES 1 AND 2 - Scanning electron micrographs of the root canal dentin surface irrigated with 17\% EDTAC associated to $1 \% \mathrm{NaOCl}$. Middle third of the root $(350 \mathrm{X})(\mathbf{1})$. Apical third of the root (350 X) (2).
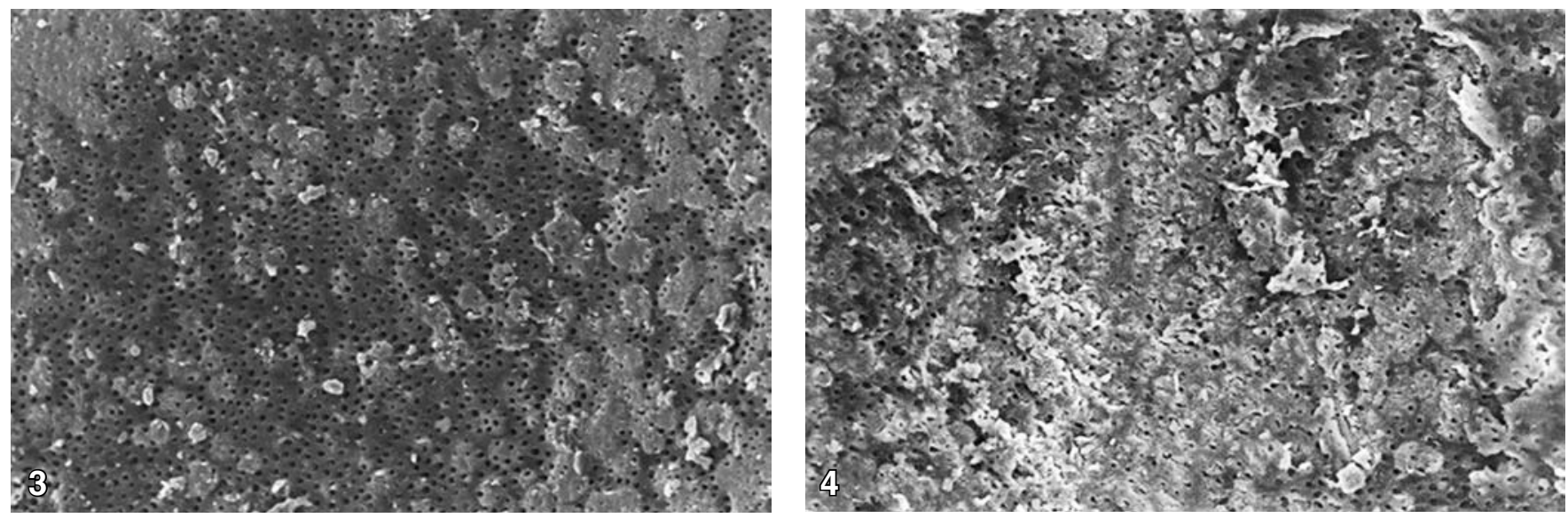

FIGURES 3 AND 4 - Scanning electron micrographs of the root canal dentin surface irrigated with a 1\% solution of sodium hypochlorite. Middle third of the root (350 X) (3). Apical third of the root (350 X) (4). 
Medici MC, Fröner IC. A scanning electron microscopic evaluation of different root canal irrigation regimens. Braz Oral Res 2006;20(3):235-40.
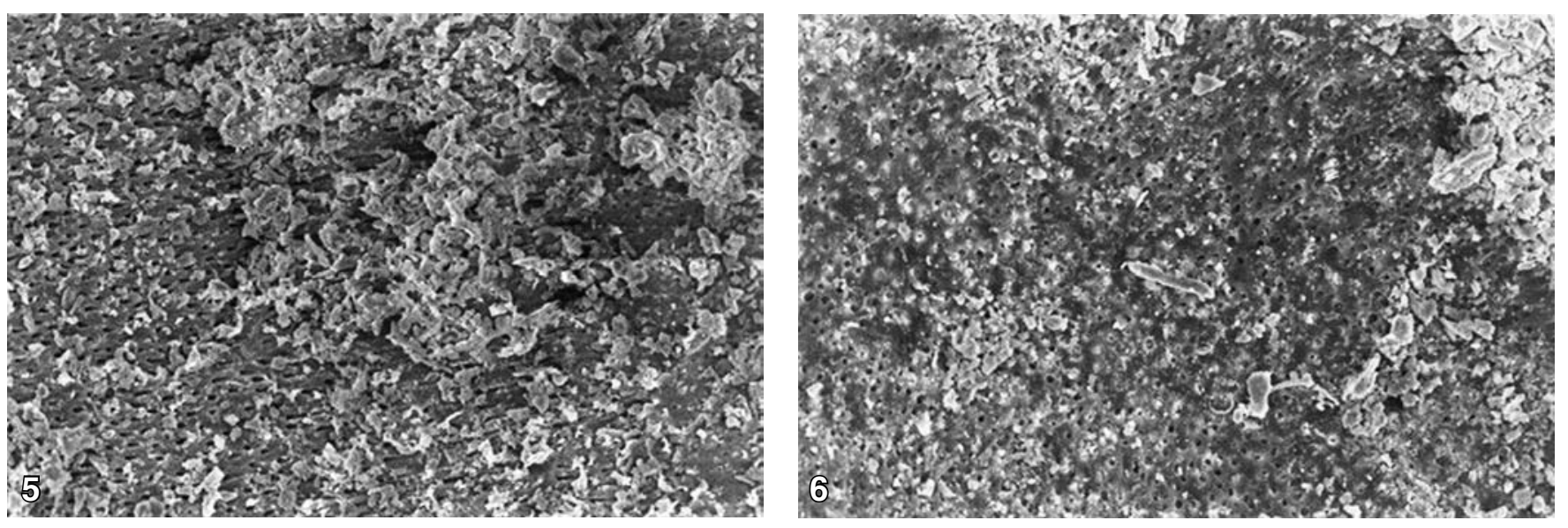

FIGURES 5 AND 6 - Scanning electron micrographs of the root canal dentin surface irrigated with a $2 \%$ chlorhexidine gluconate gel. Middle third of the root (350 X) (5). Apical third of the root (350 X) (6).
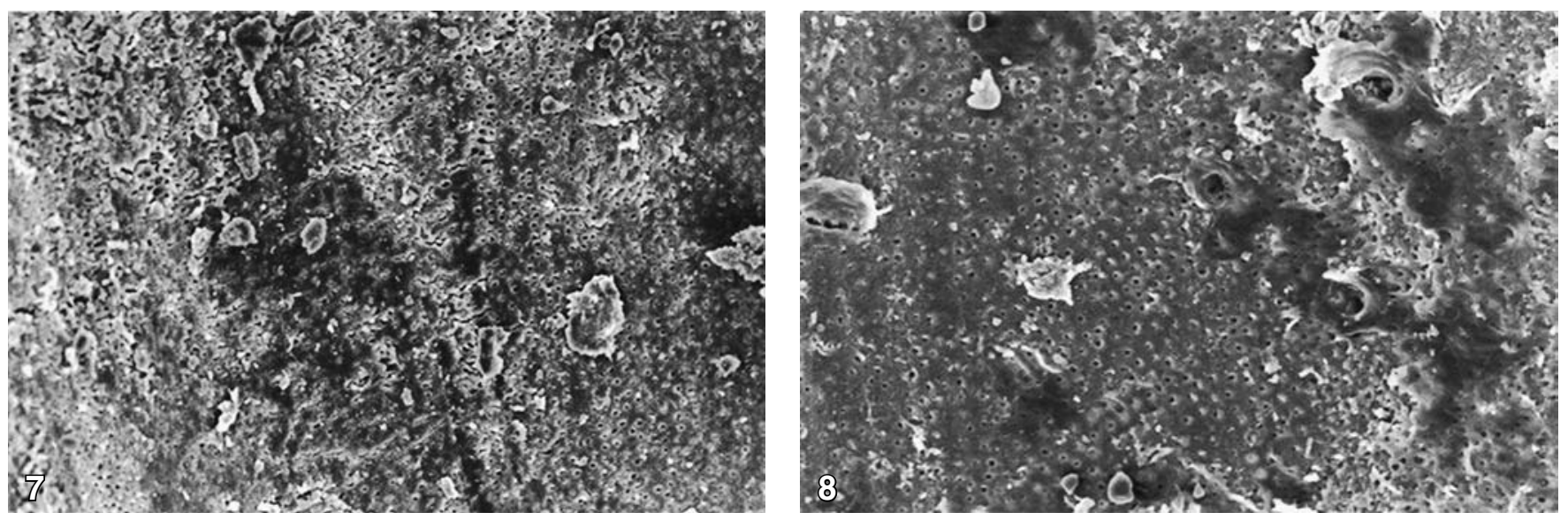

FIGURES 7 AND 8 - Scanning electron micrographs of the root canal dentin surface irrigated with a Ricinus communis gel. Middle third of the root (350 X) (7). Apical third of the root $(350 \mathrm{X})(\mathbf{8})$.

\section{DISCUSSION}

Thorough debridement of the root canal system is claimed to be essential for successful longterm endodontic therapy ${ }^{2}$. The chemomechanical preparation of root canals aims to remove debris and the smear layer. The advantages and disadvantages of the presence of the smear layer, and whether it should be removed or not from the instrumented root canals, are still controversial.

A number of substances and chemical agents have been proposed as irrigants to aid the chemomechanical instrumentation of root canals. EDTA solutions have a chelating action, biocompatibility to the periapical tissues ${ }^{23}$ and optimal cleansing ability $^{8}$. Sodium hypochlorite solutions at different concentrations have been reported to have antimicrobial activity ${ }^{3}$ and a singular ability to dissolve organic tissues ${ }^{14}$, Chlorhexidine gluconate, at con- centrations ranging from $0.2 \%$ to $2 \%$, has been reported to present tissue biocompatibility ${ }^{7}$ and an effective antibacterial action, which makes it an agent indicated worldwide for use in endodontic therapy ${ }^{1,17}$. The utilization of a castor oil detergent $\left(\right.$ Endoquil $\left.^{\mathrm{TW}}\right)$ as an irrigant has also been suggested and it has been claimed to show antimicrobial activity ${ }^{6,12,18}$ and biocompatibility with periapical tissues and structures ${ }^{19}$.

The use of a Ricinus communis gel as an auxiliary substance for root canal chemomechanical preparation discloses a great sort of possibilities in the research of chemical agents for endodontic therapy. The formulation of the gel employed in the present study is similar to that of Endoquil ${ }^{\mathrm{TM}}$, differing only in the presentation form. The intent with chlorhexidine and Ricinus communis was to assess the materials employing the same delivery vehicles. 
Medici MC, Fröner IC. A scanning electron microscopic evaluation of different root canal irrigation regimens. Braz Oral Res 2006;20(3):235-40.

The findings of the conducted research disclosed that the debridement ability of both the $2 \%$ chlorhexidine gluconate gel and the Ricinus communis gel appeared statistically similar to that of the $1 \%$ solution of sodium hypochlorite in the middle and apical thirds of the roots of mandibular premolars. However, all of these irrigants showed lesser efficiency to debride root dentin than the mixture of $1 \% \mathrm{NaOCl}$ and $17 \%$ EDTAC. None of those agents were able to completely remove the smear layer produced during root canal instrumentation. Regardless of the irrigant regimen used, no significant difference could be found between the middle and apical thirds of the roots, as regards the amount of smear layer covering dentin surface.

The results of the present work highlighted the better cleansing ability of the mixture of $17 \%$ disodium EDTAC and 1\% sodium hypochlorite, as compared to the other chemical agents evaluated. These findings corroborate those found in the literature that advocate the use of a mixture or combination of halogen and chelating substances to reach improved action on both the organic and inorganic portions of the smear layer ${ }^{2,20,25}$.

The chlorhexidine gel produced a cleaner root canal surface and yielded an antimicrobial effect when compared to the sodium hypochlorite solution and chlorhexidine liquid. The chlorhexidine gluconate in the form of gel has great potential for use as an endodontic irrigant $t^{5}$.

In the reported study, the $2 \%$ chlorhexidine and Ricinus communis gels were not able to dissolve organic tissues and showed limited effectiveness to completely remove the smear layer from dentin walls. In spite of this, both agents reached results equivalent to those of $1 \%$ sodium hypochlorite. This outcome may be attributed to the mechanical action of the endodontic instrument coupled with the viscosity of the material $1^{5,13}$.

In fact, due to its highly viscous nature, the gels are not easily removed from the root canal after instrumentation ${ }^{17}$ and some residues may be left adhered to the tooth surface. However, when a chlorhexidine-derived endodontic irrigant is used, the viscosity may be considered as a benefit, since chlorhexidine presents high substantivity and adsorbs onto the root canal dentin walls ${ }^{15}$. Therefore, it has been demonstrated that chlorhexidine-treated root dentin seems to acquire antimicrobial substantivity ${ }^{17}$. To date, there is no reported research on the substantivity of the Ricinus communis gel.

Additionally, the outcomes of the present study disclosed that the performance of the chlorhexidine gluconate and Ricinus communis gels was equivalent to that of $1 \%$ sodium hypochlorite, which is a chemical agent extensively investigated and widely used in endodontic treatment. However, the applicability of such a delivery vehicle in root canal therapy remains to be confirmed. The search for new substances for use in endodontic therapy should also be carried out in order to provide, for instance, viable options for patients with hypersensitivity to halogen solutions ${ }^{4}$.

Further investigation is certainly required to establish the effectiveness and the basis for rational applicability of both the $2 \%$ chlorhexidine gluconate gel and the Ricinus communis gel in the chemomechanical preparation of root canals.

\section{CONCLUSIONS}

The debridement ability of the $2 \%$ chlorhexidine gluconate gel and the Ricinus communis gel was comparable to that of the $1 \%$ sodium hypochlorite solution, but none of these agents was able to completely remove the smear layer. Among the irrigation regimens assessed in this study, the mixture of the $17 \%$ disodium EDTAC solution and the $1 \%$ sodium hypochlorite solution yielded the best overall results and provided root canal surfaces free from debris and the smear layer. No significant difference could be found between the middle and apical thirds of the roots.

\section{ACKNOWLEDGEMENTS}

The authors acknowledge GS Brasil for material support. This study was approved by the Research Ethics Committee of the School of Dentistry of Ribeirão Preto, University of São Paulo (process $\mathrm{n}^{\circ}$ 2001.1.893.58.0).

\section{REFERENCES}

1. Barbosa CA, Goncalves RB, Siqueira JF Jr, De Uzeda M. Evaluation of the antibacterial activities of calcium hydroxide, chlorhexidine, and camphorated paramonochlorophenol as intracanal medicament. A clinical and laboratory study. J Endod 1997;23(5):297-300.
2. Baumgartner JC, Mader CL. A scanning electron microscopic evaluation of four root canal irrigation regimens. J Endod 1987;23(2): 147-57.

3. Buck RA, Eleazer PD, Staat RH, Scheetz JP. Effectiveness of three endodontic irrigants at various tubular depths in human dentin. J Endod 2001;27(3):206-8. 
4. Caliskan MK, Turkun M, Alper S. Allergy to sodium hypochlorite during root canal therapy: a case report. Int Endod J 1994;27(2): 163-7.

5. Ferraz CC, Figueiredo de Almeida Gomes BP, Zaia AA, Teixeira FB, de Souza-Filho FJ. In vitro assessment of the antimicrobial action and the mechanical ability of chlorhexidine gel as an endodontic irrigant. J Endod 2001;27(7):452-5.

6. Ferreira CM, Bonifacio KC, Froner IC, Ito IY. Evaluation of the antimicrobial activity of three irrigation solutions in teeth with pulpal necrosis. Br Dent J 1999;10(1):15-21.

7. Foulkes DM. Some toxicological observations on chlorhexidine. J Periodontal Res Suppl 1973;12:55-60.

8. Garberolio R, Becce C. Smear layer removal by root canal irrigants: a comparative scanning electron microscopic study. Oral Surg Oral Med Oral Pathol 1994;78(3):359-67.

9. Grossman LI, Meiman BW. Solution of pulp tissue by chemical agents. J Am Dent Assoc 1941;28(1):223-5.

10. Guerisoli DMZ. Estudo, por meio de MEV, da remoção da smear layer dos canais radiculares após a aplicação de diferentes agentes quelantes e do laser Er:YAG [Dissertação de Mestrado]. Ribeirão Preto: Faculdade de Odontologia de Ribeirão Preto da USP; 2002.

11. Guimarães LEL, Robazza CRC, Murgel CAF, Pécora JD, Costa WF. Surface tension of some root canal irrigating solution. Rev Odontol Univ São Paulo 1988;2(1):6-9.

12. Ito IY, Fröner IC, Mian H, Chierice GO. Castor oil: antimicrobial activity of detergent derived from ricinolic acid [abstract]. J Dent Res 1999;78:344.

13. Jeansonne MJ, White RR. A comparison of $2.0 \%$ chlorhexidine gluconate and $5.25 \%$ sodium hypochlorite as antimicrobial endodontic irrigants. J Endod 1994;20(6):276-8.

14. Johnson BR, Remeikis NA. Effective shelf-life of prepared sodium hypochlorite solution. J Endod 1993;19(1):40-3.

15. Komorowski R, Grad H, Wu XY, Friedman S. Antimicrobial substantivity of chlorhexidine-treated bovine root dentin. J Endod 2000;26(6):315-7.
16. Kuruvilla JP, Kamath P. Antimicrobial activity of $25 \%$ sodium hypochlorite and $0.2 \%$ chlorhexidine gluconate separately and combined, as endodontic irrigants. J Endod 1998;24(7):472-6.

17. Lenet BJ, Komorowski R, Wu XY, Huang J, Grad H, Lawrence HP et al. Antimicrobial substantivity of bovine root dentin exposed to different chlorhexidine delivery vehicles. J Endod 2000;26(11):652-5.

18. Leonardo MR, Da Silva LA, Filho MT, Bonifácio KC, Ito IY. In vitro evaluation of the antimicrobial activity of a castor oil-based irrigant. J Endod 2001;27(3):717-9.

19. Mantesso A, Fröner IC, Chierice GO, Jaeger MMM. In vitro citotoxic evaluation of the Mamona solution [abstract]. J Dent Res 2001;79:1075.

20. O'Connell MS, Morgan LA, Beeler WJ, Baumgartner JC. A comparative study of smear layer removal using different salts of EDTA. J Endod 2000;26(12):739-43.

21. Ostby NB. Chelation in root therapy. Ethylenediamine tetra-acetic acid for cleansing and widening of root canals. Odont Tidsfrift 1957;65(2):3-1.

22. Pécora JD, Marchesan M, Souza Neto M, Guerisoli DMZ, Da Silva RS. Effects of Ricinus communis detergent and pain gel on radicular permeability. J Israel Dent Assoc 2000;17(2):9-11.

23. Segura JJ, Calva JR, Guerrero JM, Jimenez-Planas A, Sampedro C, Llamas R. EDTA inhibits in vitro substrate adherence capacity of macrophages: endodontic implications. J Endod 1997;23(4):205-8.

24. White RR, Hays GL, Janer LR. Residual antimicrobial activity after canal irrigation with chlorhexidine. J Endod 1997;23(4):229-31.

25. Yamada R, Armas A, Goldman M, Pin P. Scanning electron microscopic comparison of a high volume final flush with several irrigating solutions: part 3. J Endod 1983;9(4):137-42.

Received for publication on Nov 22, 2005

Sent for alterations on Apr 05, 2006

Accepted for publication on Jun 12, 2006 